\title{
PENGEMBANGAN POTENSI MASYARAKAT BIDANG PERKULITAN DI KECAMATAN GARUM KAB BLITAR
}

\author{
Ir . Wehandaka Pancapalaga Mkes ${ }^{1)}$ Ir. Endang Sri Hartati MS ${ }^{2)}$ \\ Ir.Khusnul Khotimah MP ${ }^{3)} \mathrm{Dr}$.Ir Herwintono $\mathrm{MS}^{4)}$
}

\section{Ringkasan}

Upaya untuk meningkatkan nilai tambah dan untuk menyediakan lapangan kerja yang seluas luasnya dan membuka kesempatan wirausaha baru dalam bidang penyamakan kulit dan barang barang kulit maka perlu diciptakan Sinergitas pemerintah, swasta dan perguruan Tinggi telah menjadi kata kunci penting dalam mengembangkan kawasan industri kulit di Kecamatan Garum Kabupaten Blitar.

Tujuan program IbW adalah untuk menciptakan sinergitas antara Perguruan Tinggi (Fakultas Peternakan-Perikanan UMM, Fakultas Peternakan UISBA ) Pemerintahan daerah Kabupaten Blitar dan masyarakat di Kecamatan Garum dalam pengembangan potensi masyarakat di bidang perkulitan di Kecamatan Garum Kabupaten Blitar

Metode pengembangan potensi masyarakat bidang perkulitan di Kec Garum Kab Blitar menggunakan metode PRA ( Participatory Rural Appraisal ) yaitu metode pemberdayaan potensi masyarakat yang bersifat partisipasif dan Bottom up Approach. Sedang metode yang digunakan untuk membentuk kawasan industri kecil perkulitan di Kec Garum Kab Blitar di desain dengan menggunakan pendekatan konsep cluster.

Salah satu persoalan terbesar yang dihadapi industri Penyamkan kulit adalah minimnya suplai bahan baku dari lokal daerah dalam hal inilah Kabupaten Blitar , menyusul tidak berkembangnya industri pendukung. Akibat tidak tersedianya bahan baku di daerah lokal maka pelaku industri kemudian mengambil dari daerah lain ( Surabaya, Medan dll) bisa jadi mereka impor (Malaysia , Cina dan Australia) agar proses produksi tetap bisa berjalan. Sudah bisa dipastikan, dengan menggunakan bahan baku dari luar daerah atau impor, produk kulit menjadi tidak kompetitif, baik di pasar domestik maupun ekspor, karena adanya biaya tambahan, transportasi lebih lama, serta proses importasi yang lama. Kendala Industri Kecil Penyamakan Kulit

- Tingkat utilitas produksi penyamakan rendah.

- Suplai kulit mentah didaerah terbatas.

- Mesin peralatan umumnya belum ada.

- Kualitas produksi kulit samak belum memenuhi persyaratan industri besar.

- Persaingan yang ketat dengan daerah lain sepeti Magetan , Garut, Padang .

- Pencemaran lingkungan. 
Jurnal Dedikasi Volume 7, Mei 2010

\section{A. Pandahuluan}

\section{Analisis Situasi}

Pembangunan ekonomi daerah di era otonomi menghadapi berbagai tantangan, baik internal maupun eksternal, seperti masalah kesenjangan dan iklim globalisasi. Oleh karena itu tiap daerah dituntut untuk mampu bersaing di dalam dan luar negeri. Kesenjangan dan globalisasi berimplikasi kepada propinsi dan kabupaten/ kota, untuk melaksanakan percepatan pembangunan ekonomi daerah secara terfokus melalui pengembangan kawasan dengan mengangkat produk andalannya.

Percepatan pembangunan ini bertujuan agar daerah tidak tertinggal dalam persaingan pasar bebas, seraya tetap memperhatikan masalah pengurangan kesenjangan. Karena itu seluruh pelaku memiliki peran mengisi pembangunan ekonomi daerah dan harus mampu bekerjasama melalui bentuk pengelolaan keterkaitan antarsektor, antarprogram, antarpelaku, dan antardaerah.

Potensi industri kulit memang paling kecil dibandingkan dengan potensi industri komoditi lain ( Agribisnis ayam petelur, Agribisnis buah buahan dll) di Kabupaten Blitar. Oleh karena itu pembinaan dan pengembangan potensi ini harus terus menerus ditingkatkan, khususnya dalam rangka mendukung misi yang diemban oleh sektor industri yaitu sebagai tulang punggung ekonomi nasional sekaligus untuk dapat menjadi salah satu obyek yang dapat meningkatkan nilai tambah di daerah. Untuk itu perlu dilaksanakan upaya upaya yang dapat mengoptimalkan faktor faktor yang mempengaruhi pengembangan potensi, sehingga tingkat keberhasilannya sesuai dengan yang diharapkan.

Upaya untuk meningkatkan nilai tambah dan untuk menyediakan lapangan kerja yang seluas luasnya serta membuka kesempatan wirausaha baru dalam bidang penyamakan kulit dan barang barang kulit maka perlu diciptakan Sinergitas pemerintah, swasta, dan perguruan Tinggi telah menjadi kata kunci penting dalam mengembangkan kawasan industri kulit. Paradigma pembangunan ekonomi terkini, menempatkan pemerintah bersama swasta dan Perguruan Tinggi sebagai kekuatan yang sama penting dalam setiap kebijakan, walaupun dengan peran yang berbeda . Makna sinergitas antara pemerintah dan swasta ini penting karena terjadi kebutuhan yang saling melengkapi diantaranya keduanya . Pemerintah memiliki sumberdaya yang terbatas untuk mewujudkan kesejahteraan bagi rakyatnya , tetapi memiliki kewenangan dalam kekuasaan, sementara sektor swasta memiliki kemampuan spesifik dalam menghasilkan nilai tambah dari faktor-faktor produksi, tapi tidak memiliki kewenangan yang diperlukan untuk mengelola iklim usaha yang kondusif sebagai prasyarat bagi tumbuh kembang bisnisnya. Sedang Perguruan Tinggi sebagai gudang ilmu pengetahuan dan Teknologi / Iptek yang belum secara sengaja ditujukan bagi kesejahteraan masyarakat.

Dalam rangka untuk meningkatkan nilai tambah dan menyediakan lapangan kerja seluas luasnya bagi masyarakat Kecamatan Garum untuk itu Program IbW dengan tema Pengembangan Potensi Masyarakat Bidang Perkulitan di diarahkan 
Wehandaka.Pengembangan Potensi Masyarakat Bidang Perkulitan.

untuk meningkatkan keterlibatan aktif masyarakat, Perguruan Tinggi dan Pemkab Blitar dalam membentuk Kec Garum menjadi daerah Kawasan Industri Kulit yang pada akhirnya diharapkan dapat meningkatkan Pendapatan Asli Daerah (PAD) sehingga secara tidak langsung meningkatkan kesejahteraan masyarakat.

\section{Perumusan Masalah}

Upaya untuk mengembangkan potensi bidang perkulitan di Kecamatan Garum Kabupaten Blitar maka harus mempunyai keunggulan kompetitif . Adapun keunggulam kompetitif itu ditentukan oleh empat faktor yaitu biaya produksi rendah, iklim usaha yang kondusif, skala ekonomi dan kemampuan menyerap teknologi informasi. Permasalahannya adalah apakah kawasan di Kecamatan Garum dan Kabupaten Blitar secara umum telah mempunyai keunggulan kompetitif tersebut.

\section{Tujuan IbW}

Tujuan program IbW secara umum adalah untuk menciptakan sinergitas antara Perguruan Tinggi ( Fakultas PeternakanPerikanan UMM, Fakultas Peternakan UISBA ) Pemerintahan daerah Kabupaten Blitar dan masyarakat di Kecamatan Garum dalam pengembangan potensi masyarakat di bidang perkulitan di Kecamatan Garum Kabupaten Blitar, secara khusus tujuan program IbW ini meliputi :

1. Merumuskan usulan atau program dalam pengembangan potensi masyarakat di bidang perkulitan yang berbasis potensi daerah mencakup SDM dan SDA di kecamatan Garum Kabupaten Blitar .
2. Meningkatkan ketrampilan penyamakan kulit dan ketrampilan pembuatan barang barang kulit bagi masyarakat di Kecamatan Garum di Kabupaten Blitar .

3. Menciptakan Usaha Kecil Menengah di bidang penyamakan kulit dan barang barang kulit yang mandiri di Kecamatn Garum Kabupaten Blitar

4. Mengembangkan jaringan kerjasama antara para peternak , pengepul dan pengawetan kulit , industri kecil penyamakan kulit serta industri barang barang kulit

5. Meningkatkan wawasan ekonomi sosial dan budaya bagi Dosen dan Mahasiswa dalam mengembangkan potensi daerah Kecamatan Garum Kabupaten Blitar menjadi kawasan Perkulitan

\section{Manfaat IbW}

Berdasarkan Tujuan tersebut manfaat yang diharapkan dari progran IbW ini adalah sebagai berikut :

1. Terbentuknya program pengembangan potensi masyarakat di bidang Perkulitan yang berbasis potensi daerah mencakup SDM dan SDA di Kecamatan Garum Kabupaten Blitar diharapkan dapat mendorong investor dan masyarakat sekitar terlibat langsung dan bisa mewujudkan rencana tersebut.

2. Meningkatnya ketrampilan penyamakan kulit dan ketrampilan pembuatan barang barang kulit bagi masyarakat di Kecamatan Garum di Kabupaten Blitar 
Jurnal Dedikasi Volume 7, Mei 2010

diharapkan dapat membuka lapangan usaha baru

3. Terciptanya atau munculnya wirausaha baru ( UKM) di bidang penyamakan kulit dan barang barang kulit yang mandiri di Kecamatan garum Kabupaten Blitar diharapkan dapat meningkatkan kesejahteraan masyarakat

4. Terbentuknya jaringan kerja antara para peternak, pengepul dan pengawetan kulit , industri kecil penyamakan kulit serta industri barang barang kulit diharapkan akan meningkatkan keberlanjutan usaha perkulitan, yang pada akhirnya meningkatkan PAD di Kecamatan Garum Kabupaten Blitar.

5. Meningkatnya wawasan ekonomi sosial dan budaya bagi Dosen dan Mahasiswa diharapkan dapa meningkatkan aplikasi hasil penelitian dan pengabdian Dosen dan Mahasiswa diarahkan pada pengembangan perkulitan di Kecamatan Garum Kabupaten Blitar

\section{B. Materi Dan Metode Pelaksanaan \\ 1. Lokasi Sibermas \\ Program IPTEKS bagi}

Masyarakat yang di singkat dengan IbM ini difokuskan di Desa Pojok Kec Garum.

\section{Khalayak sasaran}

Khalayak Sasaran diutamakan pada masyarakat yang mempunyai keterkaitan dengan usaha perkulitan baik itu untuk menuju kawasan industri perkulitan di Kec Garum Kab Blitar .

Konsep klaster yang dikembangkan adalah selain meningkatkan SDM melalui pendidikan dan pelatihan dilanjutkan dengan pemaganggan dan inkubator juga berupaya untuk membentuk jaringan kerja ( net working ) dan mengelompokan industri inti yang saling berhubungan, baik itu industri pendukung ( supporting industries ) seperti : bahan kimia bahan assesories barang barang kulit maupun dengan industri terkait (related industries ) seperti : RPH ( rumah potong hewan ), pengepul kulit mentah , penyamak kulit , pengrajin barang barang kulit dan show room .

Manfaat cluster selain mengurangi biaya transportasi dan transaksi, juga meningkatkan efisiensi, menciptakan asset secara kolektif dan memungkinkan terciptanya inovasi.

Secara umum struktur cluster industri kecil perkulitan dapat dijelaskan sebagaimana divisualisasikan dengan gambar dibawah ini :

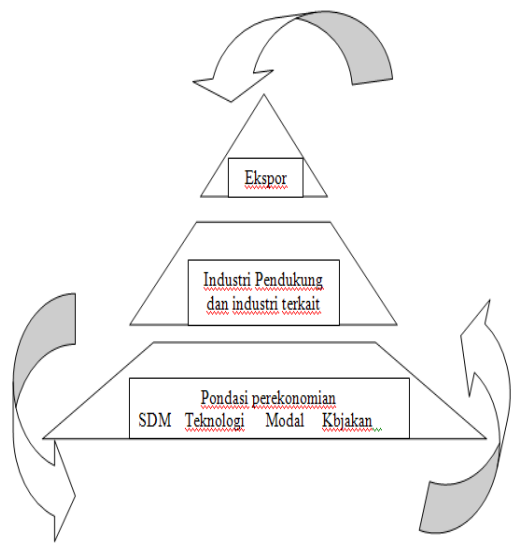


Wehandaka.Pengembangan Potensi Masyarakat Bidang Perkulitan.

\section{Target Luaran}

Target luaran yang ingin dicapai dalam program IbW dengan judul Pengembangan Potensi Masyarakat Bidang Perkulitan di Kecamatan Garum Kab Blitar dibagi dalam 3 tahun, berturut turut yaitu:

\section{Tahun I}

1. Terbentuknya usulan atau program sebagai pengembangan potensi Masyarakat iddi bidan erkulitan yang berbasis potensi daerah mencakup SDM dan SDA di Kec Garum Kab Blitar

2. Meningkatnya ketrampilan masyakat di bidang penyamakan kulit sebagai bahan baku industri barang barang kulit di Kec Garum di Kab Blitar

\section{Tahun II}

1. Meningkatnya pengetahuan kewirausahaan dan Ketrampilan usaha pembuatan barang barang kulit bagi masyarakat di Kec Garum di Kab Blitar

2. Terbentuknya jaringan kerja ( wadah Organisasi ) antara para peternak kambing, pengepul dan pengawetan kulit, industri kecil penyamakan kulit serta industri barang barang kulit dan pemasarannya.

3. Adanya kerjasama dengan pihak perbankan untuk pengembangan usaha dalam hal permodalan

\section{Tahun III}

1. Terciptanya atau munculnya wirausaha baru ( UKM) ataupun koperasi di bidang penyamakan kulit dan barang barang kulit yang mandiri di Kec Garum Kab

2. Meningkatnya aplikasi hasil penelitian dan pengabdian Dosen dan Mahasiswa pada pengembangan perkulitan di Kec Garum Blitar

\section{Hasil Dan Pembahasan}

\section{Kondisi Geografis Kec Garum}

Kecamatan Garum merupakan satu dari dua puluh dua kecamatan yang membagi habis wilayah administrasi Kabupaten Blitar. Berada di wilayah Kabupaten Blitar bagian Utara yaitu sebelah Utara sungai Brantas yang membelah Kabupaten Blitar menjadi dua bagian . Wilayah Kabupaten Blitar bagian utara ini mempunyai struktur tanah yang lebih subur dibandingkan dengan wilayah Kabupaten Bagian Selatan.

Batas batas Kecamatan Garum adalah sebagai berikut :

- Barat : Kec Nglegok Kab Blitar

- Utara : Kec Nglegok Kab Bltar

- Timur : Kec Gandusari dan Kec Talun Kab Blitar

- Selatan : Kec Kanigoro Kab Blitar

Kec Garum dengan luas wilayah

$57.47 \mathrm{~km}$ dibagi menjadi 9 desa : Desa Karangrejo merupakan desa terluas dengan luas $16.43 \mathrm{~km}$ atau $30.16 \%$ dari total luas kecamatan Garum dan desa yang mempunyai luas wilayah terkecil di kecamatan Garum adalah desa Sumberdiren dengan luas wilayah hanya $1,1 \mathrm{~km}$ atau hanya $2.02 \%$ dari luas wilayah kecamatan Garum. 
Jurnal Dedikasi Volume 7, Mei 2010

Berdasarkan data hasil pemutakhiran Master File Desa yang ada di BPS Kabupaten Blitar . Kecamatan Garum terbagi dalam 9 desa, 35 dusun / lingkungan, 108 RW dan 314 RT . dan dari hasil pendataan KBKS oleh dinas BKBKS Kabupaten Blitar pada tahun 2007 tercatat sebanyak 18.404 kepala keluarga dan 16.286 rumah tangga.

Penduduk yang menempati wilayah administrasi Kecamatan Garum sebanyak 61.706 jiwa dengan kepadatan penduduk sekitar 1.133 jiwa setiap kilometer persegi. Desa Karangrejo merupakan desa terjauh dari Ibukota Kecamatan, yaitu mempunya jarak $8 \mathrm{~km}$ dari ibukota kecamatan. Keberadaan desa dari ibukota kabupaten rata rata sekitar $9 \mathrm{~km}$, Desa Karang rejo wilayahnya paling jauh dari ibukota kabupaten sekitar $15 \mathrm{~km}$.

\section{Potensi Bahan Baku Kulit di} Kabupaten Blitar

Salah satu persoalan terbesar yang dihadapi industri Penyamkan kulit adalah minimnya suplai bahan baku dari lokal daerah dalam hal inilah Kabupaten Blitar, menyusul tidak berkembangnya industri pendukung..

Kelangkaan pasokan bahan baku kulit tidak hanya di Kabupaten Blitar saja namun hampir semua di Kota / Kab di Indonesia terjadi kelangkaan pada semua sektor industri, termasuk industri penyamakan kulit dan produk kulit (alas kaki, tas, sarung tangan, dan sebagainya). Di industri ini, kelangkaan pasokan bahan baku kulit terus terjadi, dan hingga kini belum ada solusi strategis untuk mengatasinya. Kelangkaan bahan baku kulit di dalam negeri juga dipicu oleh tidak sedikit kulit mentah yang diekspor ke luar negeri, karena harganya yang lebih menguntungkan. Padahal, tanpa diekspor pun, volume produksi kulit dalam negeri belum mampu memenuhi kebutuhan industri perkulitan domestik.

Kulit mentah Indonesia, sekalipun kualitasnya cenderung menurun akibat penanganan awal yang kurang baik, namun tetap diminati konsumen luar negeri. Pasalnya, Indonesia merupakan negara berstatus bebas penyakit mulut dan kuku (PMK) berdasarkan laporan Organisasi Kesehatan Hewan Dunia (OIE).

Hal ini merupakan daya tarik tersendiri bagi negara importir kulit yang memberlakukan kebijakan maximum security terhadap pemasukan kulit mentah. Keuntungan bagi negara importir, namun kerugian bagi Indonesia. Setelah diekspor, Indonesia akan mengimpor kembali kulit tersebut dalam bentuk barang jadi, yang harganya tentu lebih mahal.

Untuk menjamin ketersediaan pasokan bahan baku kulit di daerah kabupaten Blitar , pemerintah daerah perlu mendorong industri penyamakan kulit agar meningkatkan kualitas produknya sesuai standar kualitas yang dipersyaratkan oleh konsumen domestik. Termasuk meningkatkan kapasitas dan volume produksi, menyusun strategi pengembangan industri hulu dan hilir secara bersinergis melalui pendekatan klaster, serta meninjau kembali berbagai peraturan mengenai importasi kulit yang dinilai menghambat industri hilir.

Produksi kulit asal ternak besar dan kecil yang dihasilkan di Kabupaten Blitar ada peningkatan produksi kulit rata rata per 
Wehandaka.Pengembangan Potensi Masyarakat Bidang Perkulitan.

tahun sebesar $12.9 \%$. Khususnya tahun 2008 terjadi lonjakan peningkatan produksi kulit sebesar $44 \%$. ( Kabupaten Blitar Dalam Angka, 2008) .

Sedangkan produksi daging ayam untuk tahun 2008 menurut Kabupaten Blitar Dalam Angka ( 2008) dari jenis broiler / ayam pedaging adalah $137.675 .000 \mathrm{~kg}$, untuk jenis ayam buras $19.267 .000 \mathrm{~kg}$ dan Ayam petelor $148.077 .000 \mathrm{~kg}$ apabila di ambil rata rata berat ayam per ekor $1.7 \mathrm{~kg}$ maka jumlah ayam yang dipotong di Kab Blitar pada tahun 2008 adalah (137.675 $.000+19.267 .000+148.077 .000): 1.7=$ 179.422.941,176 ekor dengan demikian tersedia 358.845.882,352 buah kaki ayam yang siap untuk dikuliti . Maka sebagai bahan dasar suatu industri, kaki ayam cukup feasible, karena bahan bakunya tersedia cukup, mudah didapat dan harganya relatif murah. Dengan asumsi $1 \mathrm{Kg}$ kaki ayam $/$ ceker $=$ Rp 9.000 dengan isi 30 biji sehingga per biji kaki ayam Rp 300,- .

Sedang ternak kelinci populasi menyebar di seluruh Kecamatan di Kab Blitar dengan jumlah di tahun 2008 sebesar 12.147.000 ekor, populasi ini tejadi kenaikan 13,9 \% dari tahun 2004 , namun produk kulit kelinci tidak ada data yang tercatat di Kab Blitar, ini berarti bahwa ternak kelinci di Kab Blitar lebih banyak terjual diluar daerah . sebagai indikator tidak banyak warung yang menjual dengan menu dagng kelinci.

Pertumbuhan produksi daging ayam,daging sapi, daging kambing dan kelinci di Kabupaten Blitar belum banyak berpengaruh terhadap sektor industri penyamakan kulit, sebagai industri pendukungnya. Tingkat utilisasi industri penyamakan kulit saat ini masih tetap rendah. Idealnya, ketika banyak daging sapi , kambing, kelinci dan daging ayam yang dipotong di Kabupaten Blitar mulai tumbuh dan berkembang, hal ini akan berdampak positif terhadap peningkatan kapasitas produksi penyamakan kulit . Namun hal itu tidak terjadi.

Sekarang tinggal menunggu komitmen pemerintah daerah terhadap ketersediaan bahan baku kulit di Kabupaten Blitar . Dalam hal ini, tuntutan terhadap dukungan pemerintah sesungguhnya tidak hanya pada industri hulu, namun juga industri hilir. Kerja sama yang baik secara bersinergis antara Aprisindo dan Asosiasi Penyamakan Kuit Indonesia (APKI) sangat diperlukan guna menumbuhkembangkan industri pendukung. Pasalnya, tanpa dukungan industri penyamakan kulit yang kuat, sulit mengembangkan industri produk kulit yang berdaya saing.

\section{Prinsip/Strategi Dasar Pengembangan Potensi Bidang Perkulitan \\ 3.1. Fokus}

Berdasarkan pertimbangan kedekatan sumber bahan baku kulit dan adanya pelaku usaha meski sedikit, menjangkau banyak masyarakat , mempunyai keterkaitan yang luas sekaligus dampak berganda, maka pengembangan potensi bidang perkulitan yang ada di Kabupaten Blitar menjadi fokus pilihan khususnya kulit ternak kecil .

\subsection{Industri Pendorong}

Pengembangan Potensi bidang perkulitan sangat memperhatikan industri kecil dan menengah. Berdasarkan kriteria pemilihan industri pendorong di kawasan · 
Jurnal Dedikasi Volume 7, Mei 2010

ini, yaitu industri yang padat karya, berbasiskan keterampilam yang banyak menyerap tenaga kerja, bernilai investasi relatif tidak terlalu besar, serta memungkinkan diusahakan dalam skala usaha rumah tangga, maka industri pendorong di daeran Kab Blitar adalah industri kecil menengah penyamakan kulit dan barang jadi dari kulit kaki ayam dan kelinci .

\subsection{Target Pasar}

Meski bahan kulit segar segar berupa kulit kaki ayam dan kulit kelinci sudah dipasarkan ke luar daerah , strategi terpadu untuk mensinergikan pengembangan ternak, industri kerajian, dan pariwisata, belum tersusun.

\subsection{Rencana Bisnis}

Saat ini, pengembangan potensi penyamakan kulit dan barang barang kulit di Kec Garum maupun diluar daerah SIBERMAS belum didukung rencana bisnis yang terfokus pada masing-masing produk unggulan prioritas.

\subsection{Skenario Keterkaitan}

Keterpaduan dan keterkaitan dikembangkan melalui strategi keterkaitan antarkomoditas, hulu-hilir, industri dengan SDA lokal, dan antarpelaku. Kec Garum , berdasarkan potensi pengembangannya, sektor pariwisata akan banyak membantu untuk pengembangan potensi kerajinan barang barang kulit .

\subsection{Peran Pemerintah}

Sebagai fasilitator, pemerintah telah melakukan beberapa kebijakan, di antaranya peningkatan kualitas pelayanan publik dan profesionalisme aparatur, penciptaan dan penyediaan regulasi dalam penanaman modal dan dunia usaha yang kondusif, peningkatan keamanan, serta peningkatan kemudahan ijin bagi dunia usaha. Demikian pula sebagai katalisator, pemerintah telah meningkatkan peran serta masyarakat, dunia usaha, dan lembaga non pemerintah, mewujudkan kerjasama yang harmonis, serta peningkatan dukungan terhadap sektor perbankan dalam membiayai pembangunan.

\subsection{Kendala Pengembangan Potensi Bidang perkulitan}

Dibanding dengan kecamatan lainnya di Kabupaten Blitar, Kecamatan Garum merupakan sentra agribisnis yang relatif rendah. Kebijakan pengembangan potensi daerah yang bersifat sektoral dan belum sinergis, akan sulit mencapai visi dan misi pengembangan di Kec Garum. Keberpihakan kebijakanpun selama ini belum mengarah pada industri kecil dan menengah. Pengembangan produk industri pengolahan kulit juga menghadapi kendala, yaitu belum didukung faktor-faktor kunci pengembangan kawasan, antara lain kurang bahan bahan baku, keterbatasan tekonogi dan modal, infra struktur belum optimal, kurang keberpihakan pemodal kepada UKM, minimnya informasi, dan lainnya.Secara rinci dapat dirumuskan sebagai berikut :

- Tingkat utilitas produksi penyamakan rendah.

- $\quad$ Suplai kulit mentah didaerah terbatas.

- Mesin peralatan umumnya belum ada.

- Kualitas produksi kulit samak belum memenuhi persyaratan industri besar. 
Wehandaka.Pengembangan Potensi Masyarakat Bidang Perkulitan.

Persaingan yang ketat dengan daerah lain sepeti Magetan, Garut, Padang .

- Pencemaran lingkungan.

\section{Faktor Kunci Pengembangan Potensi Bidang Perkuitan di Kec Garum}

\section{1. $R \& D$}

Aktivitas R\&D telah didukung lembaga penelitian, yaitu lembaga riset perguruan tinggi di Fakultas Peternakan Universitas Muhammadiyah Malang dan Fakultas Peternakan Universitas Islam Balitar serta lembaga yang bekerjasama dengan lembaga daerah lainnya. Hasil penelitian dalam rangka pengembangan produk kulit dan barang barang kulit serta produk yang meyertainya , umumnya masih berupa teknologi sederhana, serta masih berorientasi pada sisi bahan baku dan produksi . untuk itu perlunya penelitian yang berakar pada permasalahan masyarakat dalam pengembangan bidang perkulitan . Secara umum, sosialisasi hasil penelitian dapat diakses untuk pengembangan potensi bidang perkulitan di Kecamatana Garum , sedang kontak langsung seperti pelatihan masih terbatas.

\subsection{SDM}

Program fasilitasi dan pendampingan belum banyak dilakukan untuk sektor bidang perkulitan, namun sektor industri sebagai sektor unggulan belum memilik program tersebut. Sektor industri juga memiliki keterbatasan kerjasama dalam pengembangan SDM dan kelembagaan, serta jumlah tenaga ahli.

\subsection{Pasar}

Berbeda dengan industri kecil lainnya yang sudah memasuki pangsa internasional ( Kendang sentul), pemasaran barang barang kulit masih pada tingkat regional (Jakarta, Bandung, Cirebon, Bogor), dan lokal, terutama bagi wisata kerajinan barang kulit . Upaya peningkatan pemasaran selama ini hanya sebatas promosi. Kegiatan market research perlu ditingkatkan dalam rangka pengembangan informasi pasar yang selama ini belum ditindaklanjuti.

\subsection{Akses terhadap Ketersediaan Infrastruktur, Modal dan Bahan Baku \\ Kondisi perbankan, koperasi, dan} lembaga keuangan mikro berpola syariah, dapat membantu kegiatan dunia usaha bidang perkulitan dalam menyediakan modal, terutama dalam bentuk kredit. Khusus memberi kemudahan bagi pelaku usaha , Bank yang ada di Kab Blitar telah bekerjasama dengan pemerintah, termasuk dinas yang terkait, melalui penjaminan. Diharapkan, dengan adanya upaya tersebut, kebutuhan bahan baku akan daging dan kulit domba dan sapi , kelinci dapat terpenuhi untuk konsumsi masyarakat sekaligus untuk bahan baku industri.

\section{Hasil Pelatihan Penyamakan Kulit \\ Kaki Ayam dan Kulit Kelinci Berbulu}

Pelatihan Penyamakan kulit kaki ayam dan kulit kelinci telah dlakukan selama 1 minggu mulai tanggal 10 sampai tanggal 16 Agustus 2009 yang diikuti oleh 20 Peserta. Peserta mewakili dari warga yang ada di Kecamatan Garum dengan kriteria warga yang dilatih adalah yang mempunyai motivasi tinggi untuk menggerakkan usaha kecil penyamakan kulit dan barang barang kulit. 


\section{Kesimpulan Dan Saran \\ 1. Kesimpulan}

Beberapa kesimpulan dari program IbW di Kecamatan Garum sebagai berikut :

a. Pengembangan potensi daerah bidang perkulitan di Kec Garum Kab Blitar melibatkan faktor-faktor kunci pengembangan (SDM; R\&D; Pasar;

Akses terhadap Infrastruktur; Sarana Prasarana Produksi dan Bahan Baku, dan Modal;Linkage; serta Iklim Usaha), dan keterkaitan antar faktor kunci (rantai nilai) yang dijabarkan ke dalam: (1) keterkaitan antar program dan (2) keterkaitan sub-subsistem inputagroproduksi-agroindustri -output pemasaran-jasa pelayanan.

b. Pengembangan sumber daya alam dan SDM yang difokuskan pada produk unggulan tertentu dan belum dilakukan di kecamatan lain

c. kebijakan pengembangan produk kulit berdaya saing pada daerah belum berorientasi pada sasaran pasar yang jelas, yang mempengaruhi keseluruhan strategi pengembangan produksi dan pengolahan.

d. Pemerintah sebagai fasilitator dan katalisator seharusnya tetap berperan besar membangun fondasi pembangunan ekonomi, seperti pada insentif pengembangan SDM bidang perkulitan, penelitian dan pengembangan, insentif pengembangan SDM bidang perkulitan , penelitian dan pengembangan, insentif fiskal, dan kemudahan berinvestasi. Fondasi ini diakomodasikan dalam kebijakan- kebijakan pemerintah daerah.

e. Pemilihan produk unggulan berupa

bidang perkulitan yang akan diprioritaskan pengembangannya dalam di wilayah garum, belum diterjemahkan ke dalam pemahaman bersama antar sektor dan antar pelaku usaha.

f. Faktor-faktor kunci pengembangan potensi bidang perkulitan belum dimiliki oleh di wilayah garum , dan kepemilikannya pun belum diterjemahkan ke dalam subfaktor kunci, yang meliputi :

- Pengembangan SDM (lembaga, pelatihan terfokus, pendampingan, tenaga ahli),

- R\&D (lembaga, teknologi, informasi, cakupan pemanfaatan), - Pasar (outlet/pusat perdagangan, market research dan informasi pasar, jaringan pasar), - Modal (lembaga, jenis modal, pelayanan),

- Bahan baku (lembaga penyedia, jenis input),

- linkages (kerjasama antar pelaku, antar industri, antar sektor, dan antar daerah), dan iklim usaha (regulasi insentif, birokrasi dan kepemimpinan pasar dan daerah). 
Wehandaka.Pengembangan Potensi Masyarakat Bidang Perkulitan.

\section{Saran}

Diperlukan peran serta semua pihak dalam hal ini Pemda, pelaku usaha/swasta, PT dan masyarakat dalam pengembangan ekonomi suatu wilayah, oleh karena itu diharapkan semua komponen

\section{DAFTAR PUSTAKA}

Porter, Michael E., The Competitive Advantage of Nations, New York, Free Press, 1990

Porter, Michael E., Cluster and New Economics of Competition, Harvard Business Review, 1998

Rosenfeld, Stuart A., Creating Smart Systems: A Guide Cluster Strategies in Less Favoured Regions, Carrboro, North Carolina, USA: Regional Technology Stragies, 2002.

\section{Lampiran}

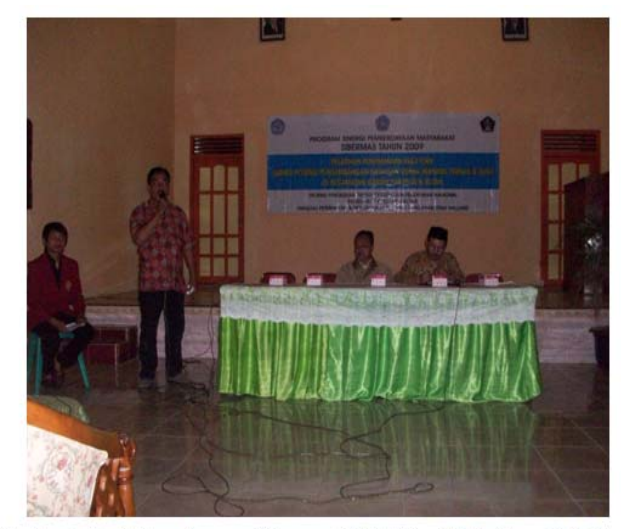

Gambar 1. Pembukaan Program Sibermas di Balai Desa Pojok Garum Kab Blitar

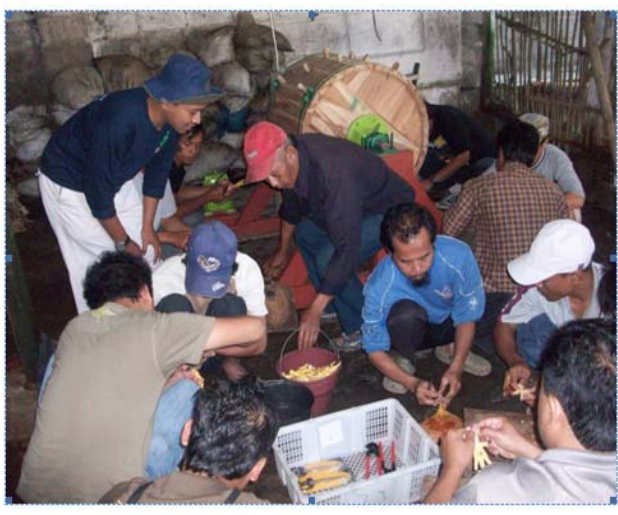

Gambar 2. Pelatihan Penyesetan Kaki Ayam

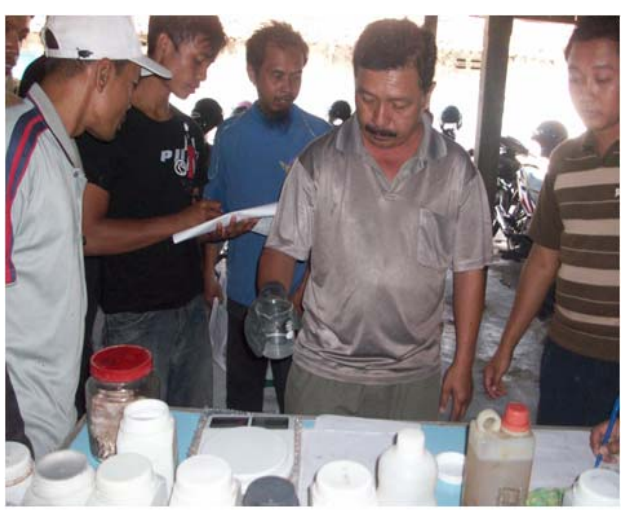

Gambar 3. Penimbangan dan penghitungan bahan kimia

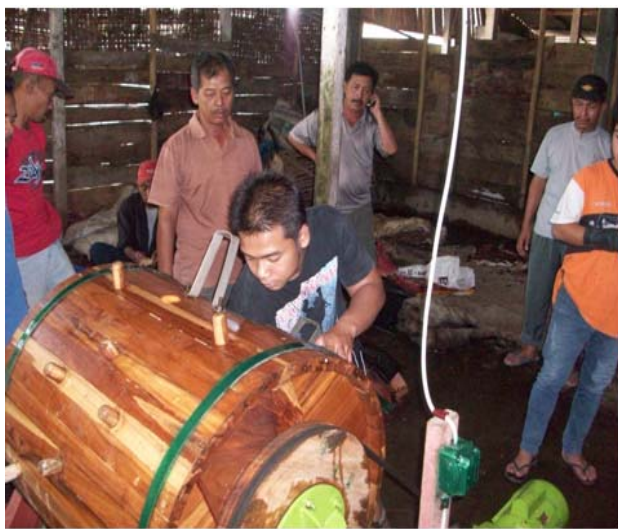

Gambar 4. Kulit siap untuk di putar dalam drum penyamakan 
Jurnal Dedikasi Volume 7, Mei 2010 